\title{
Unique aspects of red blood cell transfusion in pediatric patients
}

This article was published in the following Dove Press journal:

International Journal of Clinical Transfusion Medicine

23 May 2016

Number of times this article has been viewed

\author{
Parul Rai' \\ Shannon Kelly',2 \\ Anurag K Agrawal' \\ 'Hematology and Oncology \\ Department, Children's Hospital and \\ Research Center Oakland, Oakland, \\ CA, USA; ${ }^{2}$ Blood Systems Research \\ Institute, Blood Centers of the Pacific, \\ San Francisco, CA, USA
}

\begin{abstract}
Red blood cell transfusion plays an integral role in the management of the anemic child, and multiple factors must be considered when performing transfusions in children as compared with adults. The practitioner must be aware of the particular indication for transfusion, normal hemoglobin for age, and the need for special requirements based on the age and type of patient. Additionally, the practitioner must be aware of potential unique complications in the pediatric population and also ensure a system is in place in order to report and evaluate such potential adverse reactions. Here, we review the underlying physiological factors, symptomatology, transfusion guidelines, transfusion reactions, and potential side effects with an emphasis on those aspects that are unique to children with anemia. Many gaps remain in fully understanding pediatric red blood cell transfusion that should be addressed over time with continued research and hemovigilance.
\end{abstract}

Keywords: pediatrics, anemia, red blood cell transfusion, transfusion medicine, transfusion reaction

\section{Introduction}

Red blood cell (RBC) transfusion plays an integral role in the management of the anemic child, and multiple factors must be considered when performing transfusions in children as compared with adults. Pediatric patients require $\mathrm{RBC}$ transfusion for multiple presentations including 1) prematurity; 2) chronic diseases with underlying ineffective erythropoiesis such as $\beta$-thalassemia and sickle cell anemia (SSA); 3) congenital bone marrow failure syndromes such as Diamond-Blackfan anemia, Fanconi anemia, dyskeratosis congenita, and Schwachman-Diamond syndrome; 4) acquired bone marrow failure secondary to aplastic anemia, marrow infiltration as in hematologic malignancy, or chemotherapy-induced aplasia; 5) nutritional deficiencies, primarily iron deficiency but also folic acid or vitamin B12;6) transient erythroblastopenia of childhood; 7) chronic disease resulting in decreased erythropoietin (EPO) production as well as macrophage trapping of iron and upregulation of hepcidin leading to decreased gastrointestinal iron absorption; 8) infection resulting in bone marrow suppression such as parvovirus B19; and 9) acute presentation of blood loss often secondary to underlying gastrointestinal pathophysiology such as milk protein allergy and Meckel diverticulum or dysfunctional uterine bleeding in the adolescent female. Here, we review the underlying physiological factors, symptomatology, transfusion guidelines, transfusion reactions, and potential side effects with an emphasis on those aspects that are unique to children with anemia. 


\section{Age-dependent physiology of anemia}

The neonatal, childhood, and adolescent periods have unique physiologic properties which affect the ability to tolerate anemia. In order to increase oxygen affinity in utero, 2,3-diphosphoglycerate (2,3-DPG) levels are decreased in the fetus. Additionally, fetal hemoglobin $(\mathrm{Hb})$ does not interact with 2,3-DPG further increasing $\mathrm{Hb}$ oxygen affinity in a low oxygen tension environment. ${ }^{1}$ After birth, levels of 2,3-DPG increase while fetal $\mathrm{Hb}$ decreases to $<1 \%$ over a 6-month period in the infant with no underlying ineffective erythropoiesis. Due to the presence of fetal $\mathrm{Hb}$ at birth, tissue unloading of oxygen will be decreased, necessitating a higher baseline $\mathrm{Hb}$ concentration. ${ }^{2}$ Fetal $\mathrm{Hb}$ is also less deformable, leading to increased blood viscosity. ${ }^{2}$ Premature infants are at risk of anemia secondary to decreased endogenous EPO production and smaller total blood volume (TBV), leading to anemia from serial phlebotomy. ${ }^{2-4}$ Decreased EPO leads to the physiologic nadir at 8-10 weeks of age, which is significantly more pronounced in premature infants. ${ }^{3,4}$ Additionally, due to higher baseline heart rate, infants have a limited ability to increase myocardial contractility in response to hypovolemia. ${ }^{2}$ Infants suffering from cyanotic congenital heart disease generally have polycythemia, which can also adversely affect blood viscosity. ${ }^{2}$

Infants, children, and adolescents have increased metabolic demand as compared with adult patients. This is especially important in considering a critically ill pediatric patient with increased metabolic needs secondary to sepsis or significant trauma. ${ }^{2}$ Unlike younger children, adolescents may not tolerate the same level of anemia, such as during cancer therapy, and may require $\mathrm{RBC}$ transfusion to maintain higher $\mathrm{Hb}$ levels which can improve fatigue and quality of life. ${ }^{5}$

\section{Age-dependent signs and symptoms of anemia}

The presentation of anemia in children depends on 1) the severity of anemia, which determines the degree of reduction in oxygen carrying capacity; 2) the rapidity of onset of anemia, thus impacting the ability to compensate from a cardiovascular standpoint; 3) ongoing blood loss such as with bleeding or hemolysis; and 4) age of onset, as described earlier. Children generally have structurally intact cardiopulmonary systems allowing for compensation of severe anemia (ie, $\mathrm{Hb}<7.0 \mathrm{~g} / \mathrm{dL}$ ) with chronic onset, and can adapt without significant symptoms to an oxygen deficient state. ${ }^{6}$ The acute symptoms of anemia unique to young patients include poor feeding, irritability, and lethargy, while older children may complain of loss of appetite, fatigue, headache, dizziness, and loss of concentration, and families may note a change in behavior and school performance. Signs of anemia are often related to severity and rapidity of onset and may include pallor, tachycardia, prominent arterial pulses, tachypnea, postural hypotension, cardiac murmurs, gallop rhythm, cardiac enlargement on chest X-ray, and evidence of congestive heart failure, presenting as hepatomegaly and periorbital edema rather than peripheral edema and increased jugular venous distension as in adults. Common signs such as tachypnea and tachycardia may not be present in premature infants and may not be impacted by transfusion. ${ }^{7}$ Diseasespecific signs include frontal bossing and prominent malar and maxillary bones with extramedullary hematopoiesis in thalassemia major, as well as radial limb dysplasia and thumb anomalies in Fanconi anemia. As with adult patients, dizziness and syncope can be seen with acute blood loss. Pica behavior is common in children with iron deficiency and lead toxicity and breath holding spells can be exacerbated by concomitant severe anemia. ${ }^{8}$ Chronic anemia can adversely affect growth and development and potentially have longterm negative consequences on cognition. ${ }^{5,9}$

\section{Normal Hb levels for age}

The practitioner must be aware of normal $\mathrm{Hb}$ levels based on patient age which vary significantly over time. Jopling et al reported reference ranges for neonates and found that $\mathrm{Hb}$ concentration increased according to the formula

$$
\mathrm{Hb}=9.92+(\mathrm{GA} \times 0.2087),
$$

where GA is gestational age. ${ }^{10}$ They additionally reported the expected drop in $\mathrm{Hb}$ over the first 28 days of life based on initial GA: infants born at 35-42 weeks began with a mean $\mathrm{Hb}$ of $18 \mathrm{~g} / \mathrm{dL}$ (-2 standard deviation [SD] $14 \mathrm{~g} / \mathrm{dL}$ ), which fell to $13 \mathrm{~g} / \mathrm{dL}(-2 \mathrm{SD} 9.5 \mathrm{~g} / \mathrm{dL})$ at 28 days while $\mathrm{Hb}$ of those born at 29-34 weeks GA fell to $11 \mathrm{~g} / \mathrm{dL}$ ( -2 SD 7.8 $\mathrm{g} / \mathrm{dL}$ ). Infants born below 29 weeks invariably were transfused, making a calculation for this cohort impossible. Table 1 reports mean $\mathrm{Hb}$ and mean corpuscular volume values by age. Transfusion parameters must be implemented with consideration for normal $\mathrm{Hb}$ for age.

\section{Hb threshold for transfusion}

Different transfusion thresholds must be utilized in pediatric patients dependent on age. For anemia of prematurity, no consensus exists and practice is variable. ${ }^{2,4,11}$ Strauss suggests very general transfusion guidelines which are presented in Table 2, but also emphasizes that the guidelines must be 
Table I Red blood cell values at various ages

\begin{tabular}{llllll}
\hline \multirow{2}{*}{ Age } & \multicolumn{2}{l}{ Hemoglobin $(\mathbf{g} / \mathbf{d L})$} & & \multicolumn{2}{l}{ MCV (fL) } \\
\cline { 2 - 3 } \cline { 5 - 6 } & Mean & -2 SD & & Mean & -2 SD \\
\hline Birth (cord blood) & 16.5 & 13.5 & & 108 & 98 \\
I-3 days (capillary) & 18.5 & 14.5 & & 108 & 95 \\
I week & 17.5 & 13.5 & & 107 & 88 \\
2 weeks & 16.5 & 12.5 & & 105 & 86 \\
I month & 14.0 & 10.0 & & 104 & 85 \\
2 months & 11.5 & 9.0 & 96 & 77 \\
3-6 months & 11.5 & 9.5 & $9 \mid$ & 74 \\
0.5-2 years & 12.0 & 11.0 & 78 & 70 \\
2-6 years & 12.5 & 11.5 & 81 & 75 \\
6-I2 years & 13.5 & 11.5 & 86 & 77 \\
I2-I8 years; female & 14.0 & 12.0 & 90 & 78 \\
I2-I8 years; male & 14.5 & 13.0 & 88 & 78 \\
I8-49 years; female & 14.0 & 12.0 & 90 & 80 \\
I8-49 years; male & 15.5 & 13.5 & 90 & 80 \\
\hline
\end{tabular}

Note: Reproduced with permission from John Wiley \& Sons. Hastings CA, Torkildson JC, Agrawal AK. Handbook of Pediatric Hematology and Oncology: Children's Hospital and Research Center Oakland. 2nd ed. @ 2000 John Wiley \& Sons, Ltd. ${ }^{122}$ Abbreviations: MCV, mean corpuscular volume; SD, standard deviation.

adjusted to local practice. ${ }^{4}$ Use of a restrictive transfusion practice remains controversial in premature neonates as the methodological quality of the majority of randomized controlled trials (RCTs) trying to address this question is poor. ${ }^{11,12}$ Two well-designed studies by Bell et al and Whyte et al have shown that a more liberal transfusion practice does not expose neonates to more donors and may have benefit in the rate of major adverse neurologic events as well as potential benefit in longer term neurodevelopmental outcome. ${ }^{13,14}$ However, dos Santos et al reported that increased RBC transfusion was statistically associated with death in both univariate and multivariate analysis in very low birth weight (VLBW) premature infants, although, their results could have been confounded by the inclusion of sicker neonates who would have received more RBC transfusion. ${ }^{15}$ Controversy remains and larger, well-designed multicenter studies are required to firmly address these questions. ${ }^{11}$

Less controversy exists with regard to the risk benefit ratio of transfusion in critically ill pediatric patients. The AABB

Table 2 Red blood cell transfusion guidelines for premature neonates

Consider transfusion to maintain hemoglobin (g/dL) threshold based on clinical scenario:

$>$ II-15 for severe cardiopulmonary disease

$>10$ for moderate cardiopulmonary disease

$>10$ for major surgery

$>7-9$ for symptomatic anemia

$>7$ for asymptomatic anemia

Note: Adapted from Strauss RG. Anemia of prematurity: pathophysiology and treatment. Blood Rev. 2010;24(6):22I-225, Copyright 20I0, with permission from Elsevier. ${ }^{4}$ (formerly, the American Association of Blood Banks) recommends transfusion in both adult and pediatric intensive care units (PICUs) for $\mathrm{Hb} \leq 7 \mathrm{~g} / \mathrm{dL}$ as a high quality of evidence strong recommendation. ${ }^{16}$ In a large multicenter RCT of PICUs, Lacroix et al showed that a restrictive transfusion strategy with $\mathrm{Hb}$ threshold of $7 \mathrm{~g} / \mathrm{dL}$, rather than a liberal threshold of $9.5 \mathrm{~g} / \mathrm{dL}$, in critically ill but hemodynamically stable children decreased transfusion requirements without impacting morbidity or mortality. ${ }^{17} \mathrm{~A}$ subgroup analysis of PICU post-cardiac surgery patients similarly showed no difference in new or progressive multiple organ dysfunction, PICU length of stay or 28-day mortality between a restrictive and liberal transfusion strategy. ${ }^{18}$ In addition, a retrospective study of 657 post-cardiac surgery pediatric patients showed no difference in mortality based on amount of RBC transfusions received. ${ }^{19}$ Studies in infants undergoing cardiac surgery have shown similar results, with no benefit of a liberal transfusion practice in those with single-ventricle physiology post-cavopulmonary connection and blood transfusion being a statistically significant independent risk factor for prolonged duration of mechanical ventilation after reparative surgery. ${ }^{20,21}$ Finally, a prospective observational multicenter study of PICUs reported an adjusted significantly increased number of days of mechanical ventilation and PICU stay, rate of cardiopulmonary dysfunction, nosocomial infection, and mortality in those children who were given RBC transfusion. ${ }^{22}$

Consensus guidelines are lacking for pediatric oncology patients, and it is therefore suggested to tailor transfusion to the individual patient's needs. ${ }^{23,24}$ Considerations for transfusion must include the patient's clinical condition, anticipated procedures, presence of cardiopulmonary disease, and risk of bleeding. For young children, the effect of anemia on growth and development must be ascertained, while in adolescents, individual preference as well as the effect of anemia on fatigue and quality of life must be surmised. ${ }^{25}$ As with neonates and critically ill patients, a restrictive transfusion strategy will safely limit transfusions. Suggested prophylactic $\mathrm{RBC}$ transfusion thresholds for pediatric oncology patients are presented in Table 3.

Transfusion is commonly utilized in pediatric patients with hemoglobinopathies. Patients with $\beta$-thalassemia major ( $\beta_{0}$-thalassemia) and $E \beta_{0}$-thalassemia are transfusion dependent and require transfusion generally every 3 weeks with the goal of maintaining normal $\mathrm{Hb}$ levels and minimizing ineffective erythropoiesis. ${ }^{26}$ Patients with $\beta$-thalassemia intermedia are often the most difficult to manage as they produce enough $\beta$-globin to not require chronic transfusion, but due 
Table 3 Prophylactic red blood cell transfusion guidelines for children and adolescents with cancer

\begin{tabular}{|c|c|c|}
\hline $\begin{array}{l}\text { Clinical } \\
\text { scenario }\end{array}$ & Signs/symptoms & $\begin{array}{l}\text { Hemoglobin } \\
\text { level to transfuse } \\
(\mathrm{g} / \mathrm{dL})\end{array}$ \\
\hline Stable & $\begin{array}{l}\text { Asymptomatic child, } \\
\text { imminent hemoglobin and } \\
\text { platelet recovery }\end{array}$ & $<7$ \\
\hline Vital sign changes & $\begin{array}{l}\text { Tachycardia, tachypnea, } \\
\text { hypotension }\end{array}$ & $<8$ \\
\hline $\begin{array}{l}\text { Oxygen } \\
\text { requirement }\end{array}$ & $\begin{array}{l}\text { Pulmonary or cardiac } \\
\text { comorbidities }\end{array}$ & $8-10$ \\
\hline Thrombocytopenia & $\begin{array}{l}\text { History of prior hemorrhage } \\
\text { and PRBC requirement }\end{array}$ & $8-10$ \\
\hline Procedure & Anticipation of blood loss & $8-10$ \\
\hline Fatigue & $\begin{array}{l}\text { Negative effect on quality of } \\
\text { life, especially in adolescents }\end{array}$ & $8-10$ \\
\hline Chronic anemia & Impact on development & $8-10$ \\
\hline Infants & $\begin{array}{l}\text { Impact on growth or } \\
\text { development }\end{array}$ & $8-10$ \\
\hline $\begin{array}{l}\text { Radiation } \\
\text { (controversial) }\end{array}$ & & $8-10$ \\
\hline
\end{tabular}

Note: Reprinted with permission from Agrawal AK, Hastings $\mathrm{CH}$, Feusner J. Hematologic Supportive Care in Children With Cancer. In: Pizzo PA, Poplack DG, editors. Principles and Practice of Pediatric Oncology. 6th ed. Philadelphia: Lippincott Williams and Wilkins; $2011 .{ }^{123}$

Abbreviation: PRBC, packed red blood cell.

to phenotypic heterogeneity may develop signs of erythroid hyperplasia, including bony deformities as well as significant impact on growth and development. ${ }^{27,28}$ Some experts suggest that patients with $\beta$-thalassemia intermedia also be chronically transfused to avoid these potential complications. ${ }^{27}$ If the in utero diagnosis of $\alpha$-thalassemia major is made based on family history and prenatal findings of anemia, cardiomegaly, and hydrops, fetal transfusion can be commenced and continued after birth until the infant is old enough for curative hematopoietic stem cell transplantation (HSCT). ${ }^{29}$

Transfusion in SSA has widespread benefit and is generally underutilized. The Stroke Prevention Trial (STOP) for Sickle Cell Anemia Study showed that chronic transfusion (ie, transfusion every $3-5$ weeks with goal $\mathrm{HbS}<30 \%$ ) can prevent first stroke in pediatric patients with an abnormal transcranial Doppler ultrasound and secondarily showed improved growth and development and decreased acute chest syndrome and pain episodes in those children randomized to receive regular transfusions. ${ }^{30-33}$ Erythrocytapheresis is the ideal way to transfuse normal $\mathrm{HbA}$ while removing $\mathrm{HbS}$ and minimizing transfusional iron burden, but does expose the patient to more RBC units. ${ }^{34}$ Patients with SSA should be chronically transfused for primary stroke prevention in case of abnormal transcranial Doppler ultrasound, for secondary stroke prevention (ideally with erythrocytapheresis), and during the second and third trimester of pregnancy; acute transfusion should be performed in case of severe acute chest syndrome, acute stroke (ideally with erythrocytapheresis), during splenic sequestration, with episodes of RBC aplasia from infections such as parvovirus B19, and prior to surgery to obtain an $\mathrm{Hb}$ of $10 \mathrm{~g} / \mathrm{dL}^{34,35}$ Further data are required to fully support the decision to chronically transfuse during pregnancy. ${ }^{36}$ Whether early transfusion during a vaso-occlusive event mitigates symptoms is yet to be fully elucidated. ${ }^{37}$ Overtransfusion should be avoided due to risk of hyperviscosity and potentiating stroke. ${ }^{38}$

\section{RBC transfusion in fetal medicine and premature neonates Intrauterine transfusion (IUT) for RBC alloimmunization}

The passage of fetal RBCs across the placenta can lead to the development of red cell antibodies, which can subsequently cause significant fetal anemia due to suppressed erythropoiesis and extravascular hemolysis. IUT has been shown to be beneficial and safe at experienced centers in cases of maternal RBC IgG alloantibodies as well as RBC aplasia from parvovirus infection. ${ }^{39}$ Utilization of IUT may lead to additional RBC alloantibodies; thus, it is important to provide phenotypically matched RBCs between donor and mother. ${ }^{40,41}$

\section{Autologous/placental RBC transfusion}

Although technically feasible, placental RBC extraction for autologous transfusion continues to have limited applicability. ${ }^{42}$ In small pilot studies, there has been no benefit in autologous transfusion in neonates as compared with standard allogeneic transfusion. ${ }^{42,43}$ Additionally, there is limited benefit due to low volume of collection in extremely low birth weight infants. ${ }^{42,44-46}$ The shelf-life of umbilical cord blood autologous product is also shorter at 14-21 days. ${ }^{47}$ In addition to these concerns, bacterial contamination and high cost continue to hamper clinical usage. ${ }^{42,44}$

\section{RBC transfusion and intraventricular hemorrhage (IVH)}

Reports from one main group have shown potential correlation between $\mathrm{RBC}$ transfusion and either risk of developing or propagation of existing IVH in premature neonates. Baer et al first reported that $\mathrm{RBC}$ transfusion was the most significant contributor to increased odds of extending a Grade $1 \mathrm{IVH}$ to a Grade 3-4 IVH, though it remained unclear if this was secondary to underlying baseline risk in the infant or due 
to transfusion. ${ }^{48} \mathrm{~A}$ follow-up study by the same group was more conclusive showing that IVH Grade 3-4 cases were significantly more likely to have received RBC transfusion than matched controls, and each subsequent RBC transfusion doubled the risk of severe IVH. ${ }^{49}$ After reducing $\mathrm{RBC}$ transfusion from $58 \%$ to $25 \%$ in the first week of life over a 9 -year period, the same group was able to show a relatively correlated decrease in IVH from $17 \%$ to $8 \% .^{50}$ This reduction was accomplished by delaying umbilical cord clamping, milking or striping the cord, and minimizing phlebotomy as well as drawing neonatal ICU admission labs from the placenta. ${ }^{51}$ IVH occurred in the first week in $27 \%$ of those receiving $\mathrm{RBC}$ transfusion and in only $2 \%$ of those not being transfused $(P<0.001) .{ }^{50}$ Causation is uncertain, and it remains unclear if the increased IVH risk is due to biomechanical properties related to the need for RBC transfusion or due to $\mathrm{RBC}$ transfusion itself or potentially secondary to inflammatory upregulation with transfusion. ${ }^{50}$

\section{Transfusion associated necrotizing enterocolitis (TA-NEC)}

An association between transfusion and necrotizing enterocolitis (NEC) in premature neonates has been reported in the literature but it remains unclear if TA-NEC is a true entity. Multiple conflicting reports have been published; a meta-analysis by Mohamed and Shah was unable to conclusively determine correlation. ${ }^{52}$ TA-NEC appears related to late-onset NEC ( 31 weeks GA) with no difference in the prevalence of NEC based on the RBC preservative or age of stored RBCs. ${ }^{52}$ Withholding feeds during RBC transfusion may potentially decrease TA-NEC. ${ }^{52,53}$ Multiple etiological factors are proposed including impaired splanchnic blood flow before or after transfusion, inflammatory cytokines from $\mathrm{RBC}$ transfusion, ischemia/reperfusion injury, or underlying impaired intestinal angiogenesis. ${ }^{51,52}$ Data are lacking to make firm conclusions regarding either causation or etiology and further prospective multicenter studies are required.

\section{EPO to minimize premature neonatal RBC transfusion}

The conclusion of multiple studies and meta-analyses is that EPO does not play a significant role in reducing exposure to $\mathrm{RBC}$ transfusion whether given early after birth (ie, in the first 2 weeks) or later. ${ }^{54-57}$ In addition, correlation between risk of retinopathy of prematurity and early utilization of EPO in meta-analyses highlights the need to consider alternative methodologies to reduce the need for early transfusion. ${ }^{54,56}$ Although late EPO administration has been shown to fractionally decrease the number of RBC transfusions $(<1$ transfusion per infant), the clinical significance of this decrement is questionable. ${ }^{55}$

\section{RBC storage lesion}

Various changes occur to RBCs during storage including decreased 2,3-DPG, ATP depletion, membrane vesiculation, passive leakage of potassium out of RBCs, and loss of RBC deformability. Collectively, these changes are known as the $\mathrm{RBC}$ storage lesion and have been reviewed by Tinmouth et al. ${ }^{58}$ While the biochemical and morphological changes have been well documented for decades, the clinical impacts of these changes remain unclear. Multiple observational studies reviewed by Lacroix et al have reported that prolonged $\mathrm{RBC}$ storage (ie, $>7-14$ days) may impact RBC function resulting in harm to vulnerable patients. ${ }^{59}$ Hod et al showed in a murine model that transfusion of stored RBCs initiates inflammation through upregulation of non-transferrin bound iron, which subsequently leads to iron tissue deposition and enhanced bacterial growth. ${ }^{60}$ The transfusion of fresh $\mathrm{RBCs}$, on the other hand, did not lead to this inflammatory cascade. ${ }^{60} \mathrm{~A}$ meta-analysis including 21 adult studies, found that older blood was statistically correlated with increased risk of death, unrelated to type of patient or amount of RBCs transfused. ${ }^{61}$

In critically ill pediatric patients, Gauvin et al reported a significant independent increased risk of multiple organ dysfunction syndrome (MODS) in patients who received RBC transfusion $>14$ days old and increased risk of mortality if $>21$ days old. ${ }^{62}$ The significant increased risk of MODS was also demonstrated by Karam et al in addition to prolonged PICU stay for those receiving $\mathrm{RBC}$ transfusion $\geq 14$ days old but with no effect on mortality. ${ }^{63}$ However, these and other observational studies have many potential pitfalls as reviewed by Tinmouth et al as well as Zimrin and Hess. ${ }^{58,64,65}$ Three large multicenter RCTs have failed to show harm from older RBCs. ${ }^{66-68}$ In the Age of Blood Evaluation (ABLE) trial, Lacroix et al studied critically ill adults who received RBCs either an average of 6.1 versus 22.0 days old and showed no difference in 90-day mortality or any secondary outcome. ${ }^{66}$ Steiner et al recently reported the results of the Red-Cell Storage Duration Study (RECESS), a study of patients $\geq 12$ years of age undergoing cardiac surgery, and found no difference in the rate of MODS comparing RBC storage duration $\leq 10$ versus $\geq 21$ days ${ }^{67}$ And finally, the Age of Red Blood Cells in Premature Infants (ARIPI) trial at six Canadian tertiary neonatal ICUs comparing RBCs stored $<7$ days versus standard transfusion showed no difference 
in any of the major neonatal morbidities, mortality or rate of nosocomial infection. ${ }^{68}$

Multiple studies have shown the safety of older blood in premature neonates, especially in order to prevent exposure to multiple donors. ${ }^{4,57}$ Although concerns have been raised regarding the increase in cellular potassium and decrease in 2,3-DPG with age of the RBC unit, it is considered safe to transfuse an adenine saline (AS) unit up to the 42-day shelf-life, when given as small aliquots. ${ }^{4,57}$ Transfusion of CPDA-1 (citrate-phosphatedextrose-adenine) stored RBCs up to 28 days old has been shown safe in VLBW premature infants with no clinical or biochemical changes in potassium level, even with increased potassium concentration in the transfused product. ${ }^{69}$

\section{Pediatric cardiac surgery}

In high-risk pediatric cardiac surgery it remains controversial whether RBC storage duration impacts outcomes. In a retrospective study, Manlhiot et al reported that in those patients who required a significant amount of RBC transfusions ( $>4$ units or $>150 \mathrm{~mL} / \mathrm{kg}$ ) for complex surgical cases, longer storage duration by day was statistically correlated to increased in-hospital mortality, and effect on post operative bleeding was greatest for storage duration $>14$ days. ${ }^{70}$ Contradictory reports are available on the effect of $\mathrm{RBC}$ storage duration of the priming solution before and during cardiopulmonary bypass in children, with one report showing no difference, one in favor of shorter RBC storage duration, and the third in favor of older blood. ${ }^{71-73}$ Finally, Cholette et al observed that washing RBCs in pediatric cardiac surgery reduced inflammatory markers post operatively with a trend toward decreased total transfusion and mortality in those receiving washed products. ${ }^{74}$ A follow-up study by the same group reported a significantly higher infection rate in those children receiving the oldest blood, especially if those RBCs were washed. ${ }^{75}$ No data are available regarding the age of RBCs in priming for extracorporeal membrane oxygenation, though it is suggested to use the freshest blood and, if required, to irradiate immediately before issuing the product. ${ }^{76}$

\section{Guidelines for pediatric RBC transfusions \\ RBC component therapy and dosing}

Multiple anticoagulant-preservative solutions (outlined in Table 4) can be added to RBCs to allow for a longer storage period by maintaining $\mathrm{pH}$ and preventing coagulation including CPDA (35-day storage) or extended storage solutions AS-1 (Adsol, Baxter International Inc., Deerfield, IL, USA), AS-3 (Nutricel, MedSep Corporation, Covina, CA, USA), and AS-5
Table 4 Formulation of anticoagulant-additive solutions in blood collection sets

\begin{tabular}{lllll}
\hline Constituent & CPDA-I & AS-I & AS-3 & AS-5 \\
\hline Volume (mL) & 63 & 100 & 100 & 100 \\
Hematocrit (\%) & $70-80$ & $55-60$ & $55-60$ & $55-60$ \\
Sodium chloride (mg) & None & 900 & 410 & 877 \\
Dextrose (mg) & 2,000 & 2,200 & 1,100 & 900 \\
Adenine (mg) & 17.3 & 27 & 30 & 30 \\
Mannitol (mg) & None & 750 & None & 525 \\
Trisodium citrate (mg) & $\mathrm{I}, 660$ & None & 588 & None \\
Citric acid (mg) & 206 & None & 42 & None \\
Sodium phosphate & 140 & None & 276 & None \\
(monobasic) (mg) & & & & \\
\hline
\end{tabular}

Note: Reproduced with permission from John Wiley \& Sons. Strauss RG. Datadriven blood banking practices for neonatal RBC transfusions. Transfusion. 2000;40(I2):I528-I540. (C) 2000 John Wiley \& Sons, Ltd. ${ }^{124}$

Abbreviations: AS, adenine saline; CPDA, citrate-phosphate-dextrose-adenine.

(Optisol, Terumo Medical Corporation, Somerset, NJ, USA) (42-day storage). ${ }^{4,57}$ Preterm neonate and pediatric RBC dosing is generally $10-20 \mathrm{~mL} / \mathrm{kg}$ aliquots transfused at a maximum of $5 \mathrm{~mL} / \mathrm{kg}$ /hour. RBC units can be sterilely aliquoted in order to prevent exposure to multiple donors in those patients expected to require multiple $\mathrm{RBC}$ transfusions such as the premature neonate. ${ }^{2,457}$ A study comparing CPDA-1 with AS-1 in VLBW infants showed no difference in $\mathrm{Hb}$ increase when correcting for $\mathrm{Hb}$ concentration differences between products. ${ }^{77}$ The $\mathrm{RBC}$ unit should be warmed for premature neonates and if the volume of transfusion will exceed $>20 \%$ of TBV (with TBV approximated as $80 \mathrm{~mL} / \mathrm{kg}$ to a maximum of $6 \mathrm{~L}$ ). ${ }^{2}$

Concerns regarding the age of transfused $\mathrm{RBCs}$ and increase in potassium concentration are important with massive transfusion. Lee et al reviewed pediatric cases of transfusion-associated hyperkalemic cardiac arrest and observed risk factors including 1) infancy, 2) age of RBCs, 3) rate of transfusion more so than the total RBCs transfused, and 4) comorbidities, especially electrolyte derangements and hypotension. ${ }^{78}$ Massive transfusion was considered if $>35 \mathrm{~mL} / \mathrm{kg}$ were given over 3 hours or if $>70 \mathrm{~mL} / \mathrm{kg}$ were given over 24 hours. $^{78}$ Suggestions to reduce risk of transfusion-associated hyperkalemic cardiac arrest include 1) use of fresher RBCs, 2) minimizing time between irradiation and transfusion, 3) washing older irradiated RBC products, and 4) use of a peripheral intravenous catheter to decrease rate of transfusion. ${ }^{78}$ Of note, hypokalemia can also occur with massive transfusion as metabolism of citrate leads to metabolic alkalosis and an intracellular shift of potassium in addition to dilutional effects with concomitant administration of large amounts of potassium-poor solutions such as crystalloids. ${ }^{77,78}$ Citrate can additionally lead to ionized hypocalcemia, especially with massive transfusion in infants. ${ }^{77,79}$ 
The practitioner should determine the expected rate of $\mathrm{Hb}$ increase based on transfusion volume in order to prevent hypervolemia; for an AS unit with a hematocrit of 55\%-60\% without active blood loss, $\mathrm{Hb}$ should increase by $2 \mathrm{~g} / \mathrm{dL}$ for each $10 \mathrm{~mL} / \mathrm{kg}$ of transfused blood (ie, a transfusion factor of approximately 5). ${ }^{80}$ Additionally, anecdotal teaching that a period of "re-equilibration" after RBC transfusion is required before obtaining an accurate $\mathrm{Hb}$ measurement has been disproven in both neonatal and pediatric patients. ${ }^{80,81}$

\section{Leukoreduction and irradiation}

Based on adult studies, leukoreduction has been reported to significantly reduce febrile nonhemolytic transfusion reactions (FNHTRs) and cytomegalovirus (CMV) transmission and may be effective in reducing transmission of additional infectious agents as well as attenuating transfusion-related immunomodulation. ${ }^{82}$ Universal leukoreduction of RBCs for premature neonates has been shown to improve outcomes, though did not impact bacteremia from transfusion or overall mortality. ${ }^{83} \mathrm{~A}$ retrospective study of line infections in adult and pediatric patients reported a significant decrease in infection rate after implementation of universal leukoreduction. ${ }^{84}$ In order to prevent transfusion-associated graft-versus-host disease, immunocompromised pediatric patients including premature infants as well as those with immunodeficiencies or undergoing chemotherapy or HSCT should receive irradiated RBCs. ${ }^{85}$

\section{CMV seronegative RBC transfusion}

Risk of CMV transmission remains a concern in immunocompromised CMV-seronegative pediatric patients including premature neonates and those undergoing chemotherapy, HSCT, and solid organ transplantation. ${ }^{86}$ Although leukoreduction reduces risk of transmission to the same order of magnitude as $\mathrm{CMV}$-seronegative blood products, controversy remains that the risk of transmission remains significantly higher with leukoreduction alone. ${ }^{86-88}$ Leukoreduction significantly reduces viral burden but does not completely remove CMV from blood components. ${ }^{89}$ Therefore, consensus guidelines continue to recommend CMV-seronegative, leukoreduced RBCs for the highest-risk pediatric populations, namely, premature infants born to CMV-negative (or CMVunknown) mothers, those with potential immunodeficiencies, and those receiving $\mathrm{HSCT} .{ }^{90,91}$

\section{Special considerations in pediatric patients} Severe chronic anemia

Generally, due to normal underlying cardiopulmonary status, pediatric patients can adapt to severe anemia of slow onset by increasing plasma volume to near normal levels. Given this underlying physiology, concern exists for the development of transfusion-associated circulatory overload with cardiogenic pulmonary edema and cardiac decompensation with rapid transfusion in such patients (ie, $\mathrm{Hb} \leq 5 \mathrm{~g} / \mathrm{dL}$ ). Although slow transfusion is often recommended, data to support this are lacking, and two studies have shown the safety of transfusion of at least $2 \mathrm{~mL} / \mathrm{kg} /$ hour in patients without signs of cardiac failure or circulatory overload. ${ }^{92,93}$

\section{Hyperleukocytosis}

Pediatric patients with acute myelogenous and acute lymphoblastic leukemias can present with hyperleukocytosis or white blood cell counts $\geq 100 \times 10^{9} / \mathrm{L}$ with resultant risk of leukostasis. In order to maintain a stable cytocrit, the body will compensate by reducing the erythrocrit, and anemia is common secondary to this compensation as well as due to underlying bone marrow dysfunction..$^{94} \mathrm{RBC}$ transfusion should be used judiciously in such cases in order to not increase the cytocrit and worsen leukostasis; Hb levels $>10 \mathrm{~g} / \mathrm{dL}$ should be avoided. ${ }^{95}$

\section{Radiation therapy}

Although tumor hypoxia may play a role in the efficacy of radiation therapy, it remains unclear if treatment of anemia improves tissue hypoxia and thereby improves outcomes in oncology patients. ${ }^{96-98}$ Although many pediatric oncologists will transfuse to $\mathrm{Hb}$ levels $\geq 9 \mathrm{~g} / \mathrm{dL}$ during radiation therapy, data supporting the efficacy of such a practice are lacking. ${ }^{24}$

\section{Jehovah's Witness}

Families that are Jehovah's Witness must balance the tenets of their belief system that preclude the use of blood or blood products in any form with the potential needs of their child. Although adult patients may refuse transfusion, the rights of parents to make this decision for their child have been refuted by the legal system. ${ }^{99-101}$ Whenever possible, alternative methods for augmentation of $\mathrm{Hb}$, such as through utilization of EPO, should be employed, and hospitals should have policies in place for "bloodless" surgeries to minimize blood loss and need for transfusion in such circumstances. ${ }^{102}$ If necessary, a court order can be obtained to allow for RBC transfusion, a practice that most Jehovah's Witness families find acceptable in emergent situations. ${ }^{101}$

\section{Directed donation}

Many families will inquire about direct donation given the presumed risk of infection from $\mathrm{RBC}$ transfusion, although 
data supporting directed donor blood being safer than the screened donor pool are lacking and there is also a high wastage rate. ${ }^{103,104}$ For patients potentially undergoing HSCT, the risk of directed donor RBC transfusion from a biological parent includes development of significant RBC alloantibodies. Given these risks and potential lack of benefit, there remain scenarios where directed donation can be considered and should be discussed with the family. Strauss et al observed that biological parents can feasibly serve as blood donors for their premature neonate in a safe fashion and limit donor exposure. ${ }^{105}$

\section{Transfusion complications unique to pediatric patients}

Transfusion complications that are generally common between adult and pediatric patients include acute hemolytic transfusion reactions, FNHTRs, allergic transfusion reactions, delayed hemolytic transfusion reactions, transfusion-related acute lung injury, transfusion-associated graft-versus-host disease, and infectious complications. Oakley et al compared adult and pediatric transfusion reactions and found a significantly increased incidence in the pediatric population (6.2 reactions per 1,000 transfusions versus 2.4 reactions per 1,000 in adults), including, specifically, FNHTRs, allergic transfusion reactions, and hypotensive reactions. ${ }^{106} \mathrm{~A}$ similar review of transfusion-related acute lung injury reported to the Canadian Blood Service showed an incidence of 5.58 for children and 3.75 for adults per 100,000 RBC transfusions, with the majority of pediatric cases in infants and teenagers and with no differences in presentation or outcome compared with adults. ${ }^{107}$ Lavoie observed an increased risk of adverse events in children (18 per 100,000 RBC units issued) and neonates (37 per 100,000) as compared with adults (13 per $100,000)$ in large part due to poor understanding of the special requirements for neonates and through overtransfusion. ${ }^{108}$ The risk of transfusion-associated circulatory overload is poorly defined in the pediatric population, with premature neonates and those with poor cardiac function at theoretically greater risk.

Chronically transfused pediatric populations, such as those with underlying hemoglobinopathies or congenital bone marrow failure syndromes, are at risk of RBC alloimmunization with subsequent delayed hemolytic transfusion reactions, as well as iron overload. Patients with SSA are at highest risk of alloimmunization due to the mismatch with the largely Caucasian RBC donor pool. ${ }^{109}$ Rate of pediatric alloimmunization in SSA is reported to be $\sim 30 \%$, which is significantly higher than other frequently transfused groups. ${ }^{109,110}$ Although there are concerns about cost-effectiveness, given the high rate of pediatric SSA alloimmunization, most tertiary SSA centers would initially match RBCs for at least minor antigens Rh, C, E and Kell in addition to ABO. ${ }^{11,112}$

To prevent long-term complications of iron overload, chronically transfused pediatric populations must be monitored closely through measurement of ferritin levels as well as non invasive testing such as with $\mathrm{T} 2 *$ / $\mathrm{R} 2 *$ magnetic resonance imaging or a superconducting quantum interference device given the risk of free iron deposition in the liver, heart, pancreas, and endocrine tissues with the commencement of chelation therapy as indicated. ${ }^{113-115}$ Iron overload may also be a risk factor in late effects for long-term survivors of pediatric cancer who have a high transfusion burden, such as patients with acute myelogenous leukemia and those requiring HSCT. ${ }^{116,117}$

\section{Hemovigilance}

Hemovigilance, or the reporting of adverse events related to $\mathrm{RBC}$ transfusion, is a vital component to ensure continued safety for pediatric patients. ${ }^{118}$ Hospitals are required to have policies for reporting, documenting, and evaluating the potential adverse events as well as routine assessment of the appropriateness of transfusions. ${ }^{118}$ Yet, given these requirements, pediatric transfusion remains under researched, and reports have shown significant variation in practice between children's hospitals in the USA and Canada. ${ }^{18,119}$ Surveys in the UK of transfusion practice in pediatric patients, as well as competency of junior physicians, have both shown variation in practice and potential areas of improvement, especially given the higher rate of adverse events in neonatal and pediatric patients as compared with adults. ${ }^{120,121}$

\section{Summary}

Pediatric patients have multiple unique aspects that the practitioner must consider in the process of prescribing RBC transfusions. The practitioner must be aware of the particular indication for transfusion, normal $\mathrm{Hb}$ for age, and the need for special requirements based on the age and type of patient. Finally, the practitioner must be aware of potential unique complications in the pediatric population and also ensure a system is in place in order to report and evaluate such potential adverse reactions. Many gaps remain in fully understanding pediatric RBC transfusion that should be addressed over time with continued research and hemovigilance. 


\section{Disclosure}

The authors report no conflicts of interest in this work.

\section{References}

1. Oski FA, Gottlieb AJ, Miller WW, Delivoria-Papadopoulos M. The effects of deoxygenation of adult and fetal hemoglobin on the synthesis of red cell 2,3-diphosphoglycerate and its in vivo consequences. J Clin Invest. 1970;49(2):400-407.

2. Desmet L, Lacroix J. Transfusion in pediatrics. Crit Care Clin. 2004;20(2):299-311.

3. Widness JA. Pathophysiology of anemia during the neonatal period, including anemia of prematurity. Neoreviews. 2008;9(11):e520.

4. Strauss RG. Anemia of prematurity: pathophysiology and treatment. Blood Rev. 2010;24(6):221-225.

5. Hockenberry-Eaton M, Hinds PS. Fatigue in children and adolescents with cancer: evolution of a program of study. Semin Oncol Nurs. 2000;16(4):261-272; discussion 272-278.

6. Grant MJ, Huether SE, Witte MK. Effect of red blood cell transfusion on oxygen consumption in the anemic pediatric patient. Pediatr Crit Care Med. 2003;4(4):459-464.

7. Keyes WG, Donohue PK, Spivak JL, Jones MD Jr, Oski FA. Assessing the need for transfusion of premature infants and role of hematocrit, clinical signs, and erythropoietin level. Pediatrics. 1989;84(3):412-417.

8. Colina KF, Abelson HT. Resolution of breath-holding spells with treatment of concomitant anemia. J Pediatr. 1995;126(3):395-397.

9. Draper A. Child Development and Iron Deficiency. The Oxford Brief; 1997.

10. Jopling J, Henry E, Wiedmeier SE, Christensen RD. Reference ranges for hematocrit and blood hemoglobin concentration during the neonatal period: data from a multihospital health care system. Pediatrics. 2009;123(2):e333-e337.

11. Crowley M, Kirpalani H. A rational approach to red blood cell transfusion in the neonatal ICU. Curr Opin Pediatr. 2010;22(2):151-157.

12. Venkatesh V, Khan R, Curley A, Hopewell S, Doree C, Stanworth S. The safety and efficacy of red cell transfusions in neonates: a systematic review of randomized controlled trials. $\mathrm{Br} J$ Haematol 2012;158(3):370-385.

13. Bell EF, Strauss RG, Widness JA, et al. Randomized trial of liberal versus restrictive guidelines for red blood cell transfusion in preterm infants. Pediatrics. 2005;115(6):1685-1691.

14. Whyte RK, Kirpalani H, Asztalos EV, et al. Neurodevelopmental outcome of extremely low birth weight infants randomly assigned to restrictive or liberal hemoglobin thresholds for blood transfusion. Pediatrics. 2009;123(1):207-213.

15. dos Santos AM, Guinsburg R, de Almeida MF, et al. Red blood cell transfusions are independently associated with intra-hospital mortality in very low birth weight preterm infants. J Pediatr. 2011;159(3):371-376:e1-e3.

16. Carson JL, Grossman BJ, Kleinman S, et al. Red blood cell transfusion: a clinical practice guideline from the AABB*. Ann Intern Med. 2012;157(1):49-58.

17. Lacroix J, Hebert PC, Hutchison JS, et al. Transfusion strategies for patients in pediatric intensive care units. $N$ Engl $J$ Med. 2007;356(16):1609-1619.

18. Willems A, Harrington K, Lacroix J, et al. Comparison of two redcell transfusion strategies after pediatric cardiac surgery: a subgroup analysis. Crit Care Med. 2010;38(2):649-656.

19. Székely A, Cserép Z, Sápi E, et al. Risks and predictors of blood transfusion in pediatric patients undergoing open heart operations. Ann Thorac Surg. 2009;87(1):187-197.

20. Cholette JM, Rubenstein JS, Alfieris GM, Powers KS, Eaton M, Lerner NB. Children with single-ventricle physiology do not benefit from higher hemoglobin levels post cavopulmonary connection: results of a prospective, randomized, controlled trial of a restrictive versus liberal red-cell transfusion strategy. Pediatr Crit Care Med. 2011;12(1):39-45
21. Kipps AK, Wypij D, Thiagarajan RR, Bacha EA, Newburger JW. Blood transfusion is associated with prolonged duration of mechanical ventilation in infants undergoing reparative cardiac surgery. Pediatr Crit Care. 2011;12(1):52-56.

22. Bateman ST, Lacroix J, Boven K, et al. Anemia, blood loss, and blood transfusions in North American children in the intensive care unit. $\mathrm{Am}$ J Respir Crit Care Med. 2008;178(1):26-33.

23. Buchanan GR. Blood transfusions in children with cancer and hematologic disorders: why, when, and how? Pediatr Blood Cancer. 2005;44(2):114-116.

24. Wong EC, Perez-Albuerne E, Moscow JA, Luban NL. Transfusion management strategies: a survey of practicing pediatric hematology/ oncology specialists. Pediatr Blood Cancer. 2005;44(2):119-127.

25. Rossetto CL, McMahon JE. Current and future trends in transfusion therapy. J Pediatr Oncol Nurs. 2000;17(3):160-173.

26. Olivieri NF. The beta-thalassemias. N Engl J Med. 1999;341(2): 99-109.

27. Aessopos A, Kati M, Meletis J. Thalassemia intermedia today: should patients regularly receive transfusions? Transfusion. 2007;47(5):792-800.

28. Taher AT, Musallam KM, Karimi M, et al. Overview of practices in thalassemia intermedia management aiming for lowering complication rates across a region of endemicity: the OPTIMAL CARE study. Blood. 2010;115(10):1886-1892.

29. Vichinsky EP. Clinical manifestations of $\alpha$-thalassemia. Cold Spring Harb Perspect Med. 2013;3(5):a011742.

30. Adams RJ, McKie VC, Hsu L, et al. Prevention of first stroke by transfusions in children with sickle cell anemia and abnormal results on transcranial Doppler ultrasound. N Engl J Med. 1998;339(1):5-11.

31. Wang WC, Morales KH, Scher CD, et al. Effect of long-term transfusion on growth in children with sickle cell anemia: results of the STOP trial. J Pediatr. 2005;147(2):244-247.

32. Miller ST, Wright E, Abboud M, et al. Impact of chronic transfusion on incidence of pain and acute chest syndrome during the Stroke Prevention Trial (STOP) in sickle-cell anemia. J Pediatr. 2001;139(6): 785-789.

33. Wang WC, Dwan K. Blood transfusion for preventing primary and secondary stroke in people with sickle cell disease. Cochrane Database Syst Rev. 2013;11:CD003146.

34. Quirolo K. How do I transfuse patients with sickle cell disease? Transfusion. 2010;50(9):1881-1886.

35. Hirst C, Williamson L. Preoperative blood transfusions for sickle cell disease. Cochrane Database Syst Rev. 2012;1:CD003149.

36. Okusanya BO, Oladapo OT. Prophylactic versus selective blood transfusion for sickle cell disease in pregnancy. Cochrane Database Syst Rev. 2013;12:CD010378.

37. Kelly S, Deng X, Hoppe C, Styles L. A pilot randomized trial of red blood cell transfusion for acute treatment of vaso-occlusive pain episodes in sickle cell anemia. Br J Haematol. 2015;171(2): 288-290.

38. Wayne AS, Kevy SV, Nathan DG. Transfusion management of sickle cell disease. Blood. 1993;81(5):1109-1123.

39. Pasman SA, Claes L, Lewi L, et al. Intrauterine transfusion for fetal anemia due to red blood cell alloimmunization: 14 years experience in Leuven. Facts Views Vis Obgyn. 2015;7(2):129-136.

40. Verduin EP, Schonewille H, Brand A, et al. High anti-HLA response in women exposed to intrauterine transfusions for severe alloimmune hemolytic disease is associated with mother-child HLA triplet mismatches, high anti-D titer, and new red blood cell antibody formation. Transfusion. 2013;53(5):939-947.

41. Doyle B, Quigley J, Lambert M, et al. Red cell alloimmunisation following intrauterine transfusion and the feasibility of providing extended phenotype-matched red cell units. Transfus Med. 2014; 24(5):311-315.

42. Strauss RG, Widness JA. Is there a role for autologous/placental RBC transfusions in the anemia of prematurity. Transfus Med Rev. 2010;24(2):125-129. 
43. Brune T, Garritsen H, Hentschel R, Louwen F, Harms E, Jorch G. Efficacy, recovery, and safety of RBCs from autologous placental blood: clinical experience in 52 newborns. Transfusion. 2003;43(9): 1210-1216.

44. Eichler H, Schaible T, Richter E, et al. Cord blood as a source of autologous RBCs for transfusion of preterm infants. Transfusion. 2000;40(9):1111-1117.

45. Jansen M, Brand A, von Lindern JS, Scherjon S, Walther FJ. Potential use of autologous umbilical cord blood red blood cells for early transfusion needs of premature infants. Transfusion. 2006;46(6):1049-1056.

46. Khodabux CM, von Lindern JS, van Hilten JA, Scherjon S, Walther FJ, Brand A. A clinical study on the feasibility of autologous cord blood transfusion for anemia of prematurity. Transfusion. 2008;48(8):1634-1643.

47. Khodabux CM, van Beckhoven JM, Scharenberg JG, El Barjiji F, Slot MC, Brand A. Processing cord blood from premature infants into autologous red blood cell products for transfusion. Vox Sang. 2011;100(4):367-373

48. Baer VL, Lambert DK, Henry E, Snow GL, Christensen RD. Red blood cell transfusion of preterm neonates with a Grade 1 intraventricular hemorrhage is associated with extension to a Grade 3 or 4 hemorrhage. Transfusion. 2011;15(9):1933-1939.

49. Baer VL, Lambert DK, Henry E, Snow GL, Butler A, Christensen RD. Among very-low-birth-weight neonates is red blood cell transfusion an independent risk factor for subsequently developing a severe intraventricular hemorrhage? Transfusion. 2011;51(6):1170-1178.

50. Christensen RD, Baer VL, Lambert DK, Ilstrup SJ, Eggert LD, Henry E. Association, among very-low-birthweight neonates, between red blood cell transfusions in the week after birth and severe intraventricular hemorrhage. Transfusion. 2014;54(1):104-108.

51. Christensen RD. Associations between "early" red blood cell transfusion and severe intraventricular hemorrhage, and between "late" red blood cell transfusion and necrotizing enterocolitis. Semin Perinatol. 2012;36(4):283-289.

52. Mohamed A, Shah PS. Transfusion associated necrotizing enterocolitis: a meta-analysis of observational data. Pediatrics. 2012; 129(3):529-540.

53. El-Dib M, Narang S, Lee E, Massaro AN, Aly H. Red blood cell transfusion, feeding and necrotizing enterocolitis in preterm infants. J Perinatol. 2011;31(3):183-187.

54. Ohlsson A, Aher SM. Early erythropoietin for preventing red blood cell transfusion in preterm and/or low birth weight infants. Cochrane Database Syst Rev. 2014;4:CD004863.

55. Aher SM, Ohlsson A. Late erythropoietin for preventing red blood cell transfusion in preterm and/or low birth weight infants. Cochrane Database Syst Rev. 2014;4:CD00468.

56. Aher SM, Ohlsson A. Early versus late erythropoietin for preventing red blood cell transfusion in preterm and/or low birth weight infants. Cochrane Database Syst Rev. 2012;10:CD004865.

57. Strauss RG. Controversies in the management of the anemia of prematurity using single-donor red blood cell transfusions and/or recombinant human erythropoietin. Transfus Med Rev. 2006;20(1):34-44.

58. Tinmouth A, Fergusson D, Yee IC, Hébert PC; ABLE investigators; Canadian Critical Care Trials Group. Clinical consequences of red cell storage in the critically ill. Transfusion. 2006;46(11):2014-2027.

59. Lacroix J, Hébert P, Fergusson D, et al. The Age of Blood Evaluation (ABLE) randomized controlled trial: study design. Transfus Med Rev. 2011;25(3):197-205.

60. Hod EA, Zhang N, Sokol SA, et al. Transfusion of red blood cells after prolonged storage produces harmful effects that are mediated by iron and inflammation. Blood. 2010;115(21):4284-4292.

61. Wang D, Sun J, Solomon SB, Klein HG, Natanson C. Transfusion of older stored blood and risk of death: a meta-analysis. Transfusion. 2012;52(6):1184-1195.

62. Gauvin F, Spinella PC, Lacroix J, et al. Association between length of storage of transfused red blood cells and multiple organ dysfunction syndrome in pediatric intensive care patients. Transfusion. 2010;50(9):1902-1913.
63. Karam O, Tucci M, Bateman ST, et al. Association between length of storage of red blood cell units and outcome of critically ill children: a prospective observational study. Crit Care. 2010;14(2):R57.

64. van de Watering L; Biomedical Excellence for Safer Transfusion (BEST) Collaborative. Pitfalls in the current published observational literature on the effects of red blood cell storage. Transfusion. 2011;51(8):1847-1854.

65. Zimrin AB, Hess JR. Current issues relating to the transfusion of stored red blood cells. Vox Sang. 2009;96(2):93-103.

66. Lacroix J, Hébert PC, Fergusson DA, et al. Age of transfused blood in critically ill adults. N Engl J Med. 2015;372(15):1410-1418.

67. Steiner ME, Ness PM, Assmann SF, et al. Effects of red-cell storage duration on patients undergoing cardiac surgery. $N$ Engl J Med. 2015; 372(15):1419-1429.

68. Fergusson DA, Hébert P, Hogan DL, et al. Effect of fresh red blood cell transfusions on clinical outcomes in premature, very low-birth-weight infants: the ARIPI randomized trial. JAMA. 2012;308(14):1443-1451.

69. Fernandes da Cunha DH, Nunes Dos Santos AM, Kopelman BI, et al. Transfusions of CPDA-1 red blood cells stored for up to 28 days decrease donor exposures in very low-birth-weight premature infants. Transfus Med. 2005;15(6):467-473.

70. Manlhiot C, McCrindle BW, Menjak IB, et al. Longer blood storage is associated with suboptimal outcomes in high-risk pediatric cardiac surgery. Ann Thorac Surg. 2012;93(5):1563-1569.

71. Keidan I, Amir G, Mandel M, Mishali D. The metabolic effects of fresh versus old stored blood in the priming of cardiopulmonary bypass solution for pediatric patients. J Thorac Cardiovasc Surg. 2004;127(4):949-952.

72. Ranucci M, Carlucci C, Isgrò G, et al. Duration of red blood cell storage and outcomes in pediatric cardiac surgery: an association found for pump prime blood. Crit Care. 2009;13(6):R207.

73. Mou SS, Giroir BP, Molitor-Kirsch EA, et al. Fresh whole blood versus reconstituted blood for pump priming in heart surgery in infants. $N E n g l$ J Med. 2004;351(16):1635-1644.

74. Cholette JM, Henrichs KF, Alfieris GM, et al. Washing red blood cells and platelets transfused in cardiac surgery reduces postoperative inflammation and number of transfusions: results of a prospective, randomized, controlled clinical trial. Pediatr Crit Care Med. 2012;13(3): 290-299.

75. Cholette JM, Pietropaoli AP, Henrichs KF, et al. Longer RBC storage duration is associated with increased postoperative infections in pediatric cardiac surgery. Pediatr Crit Care Med. 2015;16(3):227-235.

76. Diab YA, Wong EC, Luban NL. Massive transfusion in children and neonates. Br J Haematol. 2013;161(1):15-26.

77. Goodstein MH, Locke RG, Wlodarczyk D, Goldsmith LS, Rubenstein SD, Herman JH. Comparison of two preservations solutions for erythrocyte transfusions in newborn infants. J Pediatr. 1993;123(5):783-788.

78. Lee AC, Reduque LL, Luban NL, Ness PM, Anton B, Heitmiller ES. Transfusion-associated hyperkalemic cardiac arrest in pediatric patients receiving massive transfusion. Transfusion. 2014;54(1):244-254.

79. Barcelona SL, Thompson AA, Coté CJ. Intraoperative pediatric blood transfusion therapy: a review of common issues. Part I: hematologic and physiologic differences from adults; metabolic and infectious risks. Paediatr Anaesth. 2005;15(9):716-726.

80. Davies P, Robertson S, Hedge S, Greenword R, Massey E, Davis P. Calculating the required transfusion volume in children. Transfusion. 2007;47(2):212-216

81. Glatstein M, Oron T, Barak M, Mimouni FB, Dollberg S. Posttransfusion equilibration of hematocrit in hemodynamically stable neonates. Pediatr Crit Care Med. 2005;6(6):707-708

82. Cervia JS, Wenz B, Ortolano GA. Leukocyte reduction's role in the attenuation of infection risks among transfusion recipients. Clin Infect Dis. 2007;45(8):1008-1013.

83. Fergusson D, Hébert PC, Lee SK, et al. Clinical outcomes following institution of universal leukoreduction of blood transfusions for premature infants. JAMA. 2003;289(15):1950-1956. 
84. Blumberg N, Fine L, Gettings KF, Heal JM. Decreased sepsis related to indwelling venous access devices coincident with implementation of universal leukoreduction of blood transfusions. Transfusion. 2005;45(10):1632-1639.

85. Moroff G, Luban NL. Prevention of transfusion-associated graftversus-host disease. Transfusion. 1992;32(2):102-103.

86. Ljungman P. Risk of cytomegalovirus transmission by blood products to immunocompromised patients and means for reduction. Br J Haematol. 2004;125(2):107-116.

87. Vamvakas EC. Is white blood cell reduction equivalent to antibody screening in preventing transmission of cytomegalovirus by transfusion? A review of the literature and meta-analysis. Transfus Med Rev. 2005;19(3):181-199.

88. Nichols WG, Price TH, Gooley T, Corey L, Boeckh M. Transfusiontransmitted cytomegalovirus infection after receipt of leukoreduced blood products. Blood. 2003;101(10):4195-4200.

89. Visconti MR, Pennington J, Garner SF, Allain JP, Williamson LM. Assessment of removal of human cytomegalovirus from blood components by leukocyte depletion filters using real-time quantitative PCR. Blood. 2004;103(3):1137-1139.

90. Gibson BE, Todd A, Roberts I, et al. Transfusion guidelines for neonates and older children. Br J Haematol. 2004;124(4):433-453.

91. Blajchman MA, Goldman M, Freedman JJ, Sher GD. Proceedings of a consensus conference: prevention of post-transfusion CMV in the era of universal leukoreduction. Transfus Med Rev. 2001;15(1):1-20.

92. Jayabose S, Tugal O, Ruddy R, Wuest D, Ciavarella D. Transfusion therapy for severe anemia. Am J Pediatr Hematol Oncol. 1993;15(3): 324-327.

93. Agrawal AK, Hsu E, Quirolo K, Neumayr LD, Flori HR. Red blood cell transfusion in pediatric patients with severe chronic anemia: how slow is necessary? Pediatr Blood Cancer. 2012;58(3):466-468.

94. Lichtman MA, Rowe JM. Hyperleukocytic leukemias: rheological, clinical, and therapeutic considerations. Blood. 1982;60(2):279-283.

95. Harris AL. Leukostasis associated with blood transfusion in acute myeloid leukaemia. Br Med J. 1978;1(6121):1169-1171.

96. Vaupel P, Thews O, Hoeckel M. Treatment resistance of solid tumors: role of hypoxia and anemia. Med Oncol. 2001;18(4):243-259.

97. Brizel DM, Dodge RK, Clough RW, Dewhirst MW. Oxygenation of head and neck cancer: changes during radiotherapy and impact on treatment outcome. Radiother Oncol. 1999;53(2):113-117.

98. Prosnitz RG, Yao B, Farrell CL, Clough R, Brizel DM. Pretreatment anemia is correlated with the reduced effectiveness of radiation and concurrent chemotherapy in advanced head and neck cancer. Int $J$ Radiat Oncol Biol Phys. 2005;61(4):1087-1095.

99. Penson RT, Amrein PC. Faith and freedom: leukemia in Jehovah Witness minors. Onkologie. 2004;27(2):126-128.

100. Aguilera P. [Blood transfusions in Jehovah's witnesses]. Rev Med Chil. 1993;121(4): 447-451. Spanish.

101. Ridgway D. Court-mediated disputes between physicians and families over the medical care of children. Arch Pediatr Adolesc Med. 2004;158(9):891-896.

102. Cothren C, Moore EE, Offner PJ, Haenel JB, Johnson JL. Blood substitute and erythropoietin therapy in a severely injured Jehovah's witness. N Engl J Med. 2002;346(14):1097-1098.

103. Wales PW, Lau W, Kim PC. Directed donation in pediatric general surgery: is it worth it? J Pediatr Surg. 2001;36(5):722-725.

104. Knuckey MI, Wood EM, Savoia HF. Audit of a paediatric directed donation programme. J Paediatr Child Health. 2003;39(5): 364-367.

105. Strauss RG, Burmeister LF, Johnson K, Cress G, Cordle DG. Randomized trial assessing the feasibility and safety of biologic parents as RBC donors for their preterm infants. Transfusion. 2000;40(4): $450-456$.
106. Oakley FD, Woods M, Arnold S, Young PP. Transfusion reactions in pediatric compared with adult patients: a look at rate, reaction type, and associated products. Transfusion. 2015;55(3):563-570.

107. Lieberman L, Petraszko T, Yi Q, Hannach B, Skeate R. Transfusionrelated lung injury in children: a case series and review of the literature. Transfusion. 2014;54(1):57-64.

108. Lavoie J. Blood transfusion risks and alternative strategies in pediatric patients. Paediatr Anaesth. 2011;21(1):14-24.

109. Vichinsky EP, Earles A, Johnson RA, Hoag MS, Williams A, Lubin B. Alloimmunization in sickle cell anemia and transfusion of racially unmatched blood. N Engl J Med. 1990;322(23):1617-1621.

110. Aygun B, Padmanabhan S, Paley C, Chandrasekaran V. Clinical significance of RBC alloantibodies and autoantibodies in sickle cell patients who received transfusions. Transfusion. 2002;42(1):37-43.

111. Yazdanbakhsh K, Ware RE, Noizat-Pirenne F. Red blood cell alloimmunization in sickle cell disease: pathophysiology, risk factors, and transfusion management. Blood. 2012;120(3):528-537.

112. Kacker S, Ness PM, Savage WJ, et al. Cost-effectiveness of prospective red blood cell antigen matching to prevent alloimmunization among sickle cell patients. Transfusion. 2014;54(1):86-97.

113. Angelucci E, Brittenham GM, McLaren CE, et al. Hepatic iron concentration and total body iron stores in thalassemia major. $N$ Engl J Med. 2000;343(5):327-331.

114. Brittenham GM, Sheth S, Allen CJ, Farrell DE. Noninvasive methods for quantitative assessment of transfusional iron overload in sickle cell disease. Semin Hematol. 2001;38(1 Suppl 1):37-56.

115. Wood JC, Enriquez C, Ghugre N, et al. MRI R2 and R2* mapping accurately estimates hepatic iron concentration in transfusiondependent thalassemia and sickle cell disease patients. Blood. 2005;106(4):1460-1465.

116. Ruccione KS, Mudambi K, Sposto R, Fridey J, Ghazarossian S, Freyer DR. Association of projected transfusional iron burden with treatment intensity in childhood cancer survivors. Pediatr Blood Cancer. 2012;59(4):697-702.

117. de Ville de Goyet M, Moniotte S, Robert A, et al. Iron overload in children undergoing cancer treatments. Pediatr Blood Cancer. 2013;60(12):1982-1987.

118. Bolton-Maggs PH. Transfusion and hemovigilance in pediatrics. Pediatr Clin North Am. 2013;60(6):1527-1540.

119. Spinella PC, Dressler A, Tucci M, et al. Survey of transfusion policies at US and Canadian children's hospitals in 2008 and 2009. Transfusion. 2010;50(11):2328-2335

120. New HV, Grant-Casey J, Lowe D, Kelleher A, Hennem S, Stanworth SJ. Red blood cell transfusion practice in children: current status and areas for improvement? A study of the use of red blood cell transfusions in children and infants. Transfusion. 2014;54(1):119-127.

121. Graham J, Grant-Casey J, Alston R, Baker P, Pendry K. Assessing transfusion competency in junior doctors: a retrospective cohort study. Transfusion. 2014;54(1):128-136.

122. Hastings CA, Torkildson JC, Agrawal AK. Handbook of Pediatric Hematology and Oncology: Children's Hospital and Research Center Oakland. 2nd ed. New York: John Wiley and Sons, Ltd; 2012.

123. Agrawal AK, Hastings CH, Feusner J. Hematologic Supportive Care in Children With Cancer. In: Pizzo PA, Poplack DG, editors. Principles and Practice of Pediatric Oncology. 6th ed. Philadelphia: Lippincott Williams and Wilkins; 2011.

124. Strauss RG. Data-driven blood banking practices for neonatal RBC transfusions. Transfusion. 2000;40(12):1528-1540. 


\section{Publish your work in this journal}

International Journal of Clinical Transfusion Medicine is an international, peer-reviewed, open access, online journal publishing clinicalexperimental, policy-making and evidence-based practices of all topics pertaining to clinical transfusion medicine. Original research, short reports, reviews, case reports and commentaries are invited.

The manuscript management system is completely online and includes a very quick and fair peer-review system, which is all easy to use. Visit http://www.dovepress.com/testimonials.php to read real quotes from published authors.

Submit your manuscript here: http://www.dovepress.com/international-journal-of-clinical-transfusion-medicine-journal 